\title{
Where is the Party? \\ Explaining Positions on Same-sex Marriage in Europe among Would-be MPs
}

\author{
Scott N. Siegel ${ }^{*}$, Stuart J. Turnbull-Dugarte ${ }^{\dagger}$, and Brian A. Olinger ${ }^{\ddagger}$ \\ ***Paper accepted for publication in the European Journal of Politics $\mathcal{G}$ Gender***
}

\begin{abstract}
The rapid adoption of marriage equality legislation for non-heterosexual individuals in Europe is attributed to many factors, including dramatic shifts in public opinion, the work of transnational activists or changing international norms. These factors usually must be filtered through the halls of parliament, where most policy change happens. Given the importance of parliamentarians' attitudes, it is surprising we know so little about how attitudes towards same-sex marriage (SSM) are distributed across political candidates in Europe and what factors shape them. This article fills that gap by using an under-utilized data set on the political preferences of candidates for parliamentary office. We find that, beyond attachment to party families, a candidate's religiosity and practice has a greater effect on a would-be MP's attitudes towards SSM. The findings suggest that the success of parliamentary action on LGBT rights depends not on the partisan composition of the legislature but rather on the representation of secular candidates.
\end{abstract}

Keywords: Same-sex marriage, political parties, party candidates, LGBTQ politics, Europe

\section{Key messages:}

- Support among parliamentary candidates aspiring to become legislators is an important prerequisite for the advancement of LGBT rights in polities where institutional equality is brought about via legislative reforms.

- Over and above partisanship attachment and ideological positions, the religiosity of would-be MPs is important in establishing support for LGBT rights issues like same-sex marriage.

- The success of LGBT rights advances in the legislator is likely to be more influence by the secular composition of chambers rather than the partisan composition

\section{Introduction}

Over the last two decades, a number of democracies initiated legislative reforms aimed at remedying the institutional forms of discrimination against lesbian, gay, bisexual, and transgender (LGBT) individuals. One of

\footnotetext{
* Associate Professor, San Francisco State University, USA

Corresponding author: snsiegel@,sfsu.edu

† Assistant Professor, University of Southampton, UK

¥Independent Scholar, USA
} 
the fundamental policy innovations includes the legalization of same-sex marriage (SSM). Following the entrepreneurial advocacy of social movements acting from the "ground up" (Ayoub 2016; Ayoub and Kollman 2020) and transnationally (Kollman 2017), SSM is now legalized in sixteen European states, whilst nine others have some type of recognition of same-sex partnership (SSP) laws. ${ }^{1}$ The impact on the health and welfare of LGBT couples and individuals brought about by the reforms has been significant. Not only do public policies providing equal recognition of same-sex couples have a positive and direct impact on improving the welfare of the LGBT community (Thomeer et al. 2018), they also have indirect effects. Abou-Chadi and Finnigan (2019), for example, show that the legalization of SSM exhibits a significant positive effect on public attitudes towards sexual minorities amongst European publics and similar effects have been observed in the United States (Flores and Barclay 2016). ${ }^{2}$

While changing public opinion has been shown to be a major contributor to policy change, it may not always be necessary. In some countries, SSM laws were adopted before support was above 50 percent. In others, SSM laws were delayed despite many years of polls demonstrating support exceeding 75 percent of the general public. Public opinion must be filtered through the legislative process, especially in Europe where parliamentary legislation has been the most common vehicle, with notable exceptions (Helfer and Voeten 2014), for the expansion of LGBT rights, specifically SSP/SSM laws. ${ }^{3}$

We claim that the attitudes and preferences of members of parliament are crucial to understanding if and when SSM/SSP laws are adopted. Yet, outside the United States (Bishin et al. 2020), we know little about legislators' preferences and attitudes towards LGBT rights. We fill this gap in our knowledge by presenting the first audit of political candidates' attitudes towards SSM, a core issue of equal treatment for the LGBT community. Empirically, we utilize individual-level data of about 20,000 candidates for parliamentary office across twenty-one European states over thirteen years to assess their level of support for a ban on SSM. Consistent with an analysis of other so-called "morality issues", we find that socio-demographic characteristics, specifically a candidate's degree of religious observance, affect support for SSM, even among those who belong to party families that are traditionally described as strong supporters of progressive cultural values.

\footnotetext{
${ }_{1}^{1}$ Data drawn from ILGA-Europe, “Rainbow Map 2020,” https://rainbow-europe.org/ - 0/8682/0, accessed June 20, 2021.

2 This is not a claim without contention. Earlier work highlights the backlash-inducing effects of LGBT rights reforms whereby legislative and judicial progress is met with counter mobilisation efforts that seek to repeal these advances.

${ }_{3}^{3}$ Austria legalized SSM in response to a Constitutional Court ruling in 2019. SSP laws were approved by national plebiscite in Switzerland in 2005 and Liechtenstein in 2011 but only after right-wing groups and parties opposed to the law organized optional referenda against the proposed parliamentary legislation. For the same reason, a referendum over SSM will occur in fall 2021 in Switzerland. In contrast, in 2012 and 2015, a majority of Slovenes rejected bills expanding rights for samesex couples and laws establishing SSM, respectively. A constitutional amendment to ban SSM succeeded in Croatia in 2013, although same-sex "life partnerships" were created the following year that gave same-sex couples some of the same rights as heterosexual married couples. At the same time, plebiscites have taken place in other European states that sought to constitutionally prohibit SSM. Referenda to amend the national constitutional to strengthen the constitutional bans on SSM were held in Slovakia (2015) and Rumania (2018). Although both received a majority in favour, the results were invalid due to insufficient voter participation.
} 
Our paper is structured as follows. We begin by surveying the extant literature on how partisan politics influence the timing of when marriage equality laws are adopted. We then discuss the contrasting narratives about why these "gatekeepers" may approve LGBT legislation and whether they are driven by their party affiliation or their personal beliefs about the morality of SSM. We then present the findings of our main analysis before providing a discussion of our conclusions and their implications for future research.

\section{Parties, Preferences, and Progress in LGBT Rights Policy}

Public opinion on LGBT rights, both across the developed and developing world, has changed dramatically over the last three decades. Not only has tolerance towards homosexuality risen in developed (Abou-Chadi and Finnigan 2019; Garretson 2018; Paternotte and Kollman 2013) and developing (Ayoub and Garretson 2017) countries alike, but also, perhaps as a consequence, a substantial amount of legislation and judicial decisions have expanded the legal and institutional equal treatment for some members of the LGBT community. But, the passage of legislation improving the human rights situation for sexual minorities does not move in lockstep with changes in public opinion. Relying on a dataset compiled of national-level approval for homosexuality and the cumulative number of progressive LGBT rights laws among thirty-six European countries over forty years, we illustrate in Figure 1 that there is a non-linear relationship between public opinion and the introduction of pro-LGBT laws. 


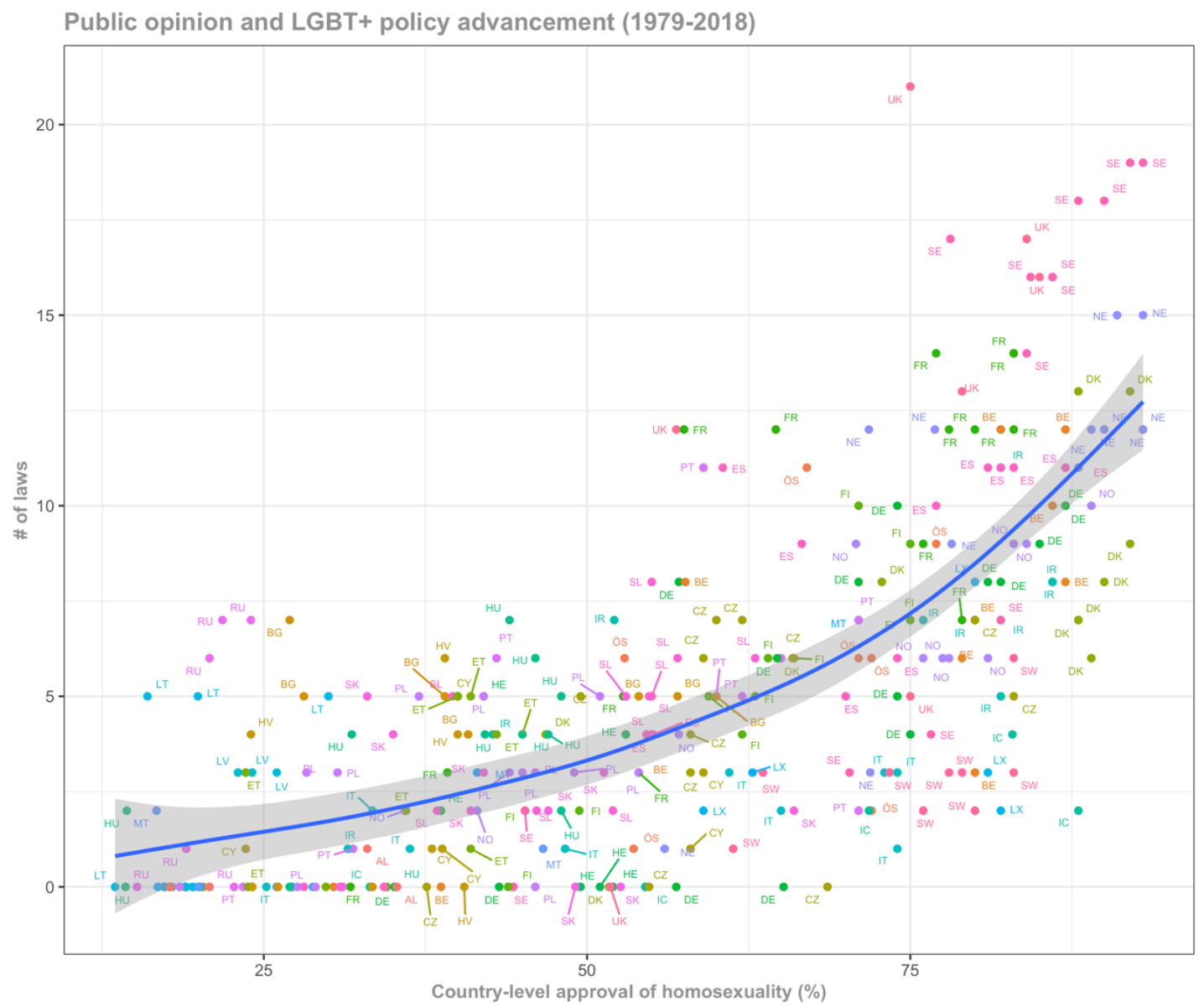

Each data point in Figure 1 is indicative of a country's number of pro-LGBT laws and the domestic approval of homosexuality in a given year. The trend line is nonlinear. There are a larger number of countries with a high tolerance of homosexuality (above the 50 percent threshold) that have adopted legal equality measures for LGBT citizens. The reverse is also true, with some states introducing more pro-LGBT laws sooner than predicted by the state of national public opinion. To give but two examples, Spain adopted SSM in 2005, despite only 62 percent of the population supporting the measure. In contrast, Switzerland has still not approved SSM despite support currently standing at over 80 percent. $^{4}$

Despite the nonlinear relationship between public opinion and LGBT rights advances, legislative action - in contrast to the central role of the judicial branch in the United States-remains the primary avenue via which LGBT rights advances have been brought about, particularly in Europe. Except for Ireland and Austria, and the partial exceptions of Finland, Switzerland, and Liechtenstein where a combination of popular initiatives and legislative action put SSP/SSM laws into place, all other SSM and SSP laws were introduced by parliamentarians. Ireland remains the only European country to legalize SSM via a referendum, and Austria is the only European country to do so through judicial action. Italy does not yet administer SSMs, but the SSP

${ }^{4}$ As of this writing, Switzerland will hold a referendum on federal legislation that approved same-sex marriages, and it is likely to be approved by a substantial majority. 
law that it does have was only introduced in response to a ruling from the European Court of Human Rights in 2016. ${ }^{5}$ Thus, while there are alternative mechanisms for the adoption of SSM laws, parliamentarian action is the primary means by which they are adopted.

Given the central role of parliamentarians in advancing LGBT rights such as SSM in Europe, assessing the preferences and attitudes of aspiring legislators is important because it allows us to better understand legislative outcomes (Trumm, Milazzo, and Townsley 2020). The role of individuals, rather than political parties, is of particular importance when it comes to LGBT rights given the dilution of the party whip. When voting on these issues, representatives are typically released from the confines of enforced party discipline and are likely to vote more in accordance with their own individual moral value system (Cowley 1998). These "free votes" reduce the partisan distinction of legislature voting behaviour, allowing individual representatives to decide how to vote based on their own preferences over different morality issues. Empirically, analyses of legislative voting behaviour show that parliamentarians rationally respond to the dilution of party constraints, voting according to their conscience, and cross-party voting coalitions emerge between representatives of different ideological colours. For example, when free votes on SSM were taken in Westminster parliamentary systems (Plumb 2015) or in Germany in 2017, there was support across the political spectrum for SSM that cannot only be explained MPs' partisan affiliation. Although the overall evidence is mixed, these examples show that the preferences of individual candidates for parliament matter as much as the ideological orientation of the incumbent government.

\section{Explaining Aspiring MPs' Preferences}

Research shows that parties have distinguishable positions on some issues of LGBT politics and there tends to be a clear left/right split on whether to expand LGBT legislation (Adam, Knill, and Budde 2020; Turnbull-Dugarte 2020a). Given the association between left-wing government incumbency and the advance of SSM/SSP laws, however, our first hypothesis is that candidates from left parties will be more supportive of SSM than candidates from the right.

H1 (Party Thesis): Candidates from traditionally left parties are more likely to oppose an SSM ban.

Yet, somewhat puzzling, centrist and centre-right parties have also favoured the adoption of SSM at different times. Siegel and Wang (2018) show that these contradictory findings are, in large part, due to relying on classical left/right measures of party ideology instead of mapping parties' positions along the post-materialist political axis. Parties on the liberal side of the post-materialist axis are more inclined to support SSM despite holding right-wing economic stances. Existing research, therefore, highlights the role of multidimensional issue

${ }^{5}$ ECtHR, Olinari and Others v Italy, Application nos. 18766/11 and 36030/11, 21 July 2015. 
preferences of political parties, particularly those related to the green/alternative/liberal vs traditional/authoritarian/nationalist (GAL-TAN) cleavage, in helping to understand party support on LGBT rights (Siegel and Wang 2018). As a result, we hypothesize that concrete ideology positions are also likely to play a role in explaining the position of aspiring party candidates' positions on SSM. Importantly, and as visualized in Figure 2, political parties identified as constituents of a particular party family type (e.g., Social Democratic or Green) often remain ideologically distinct.
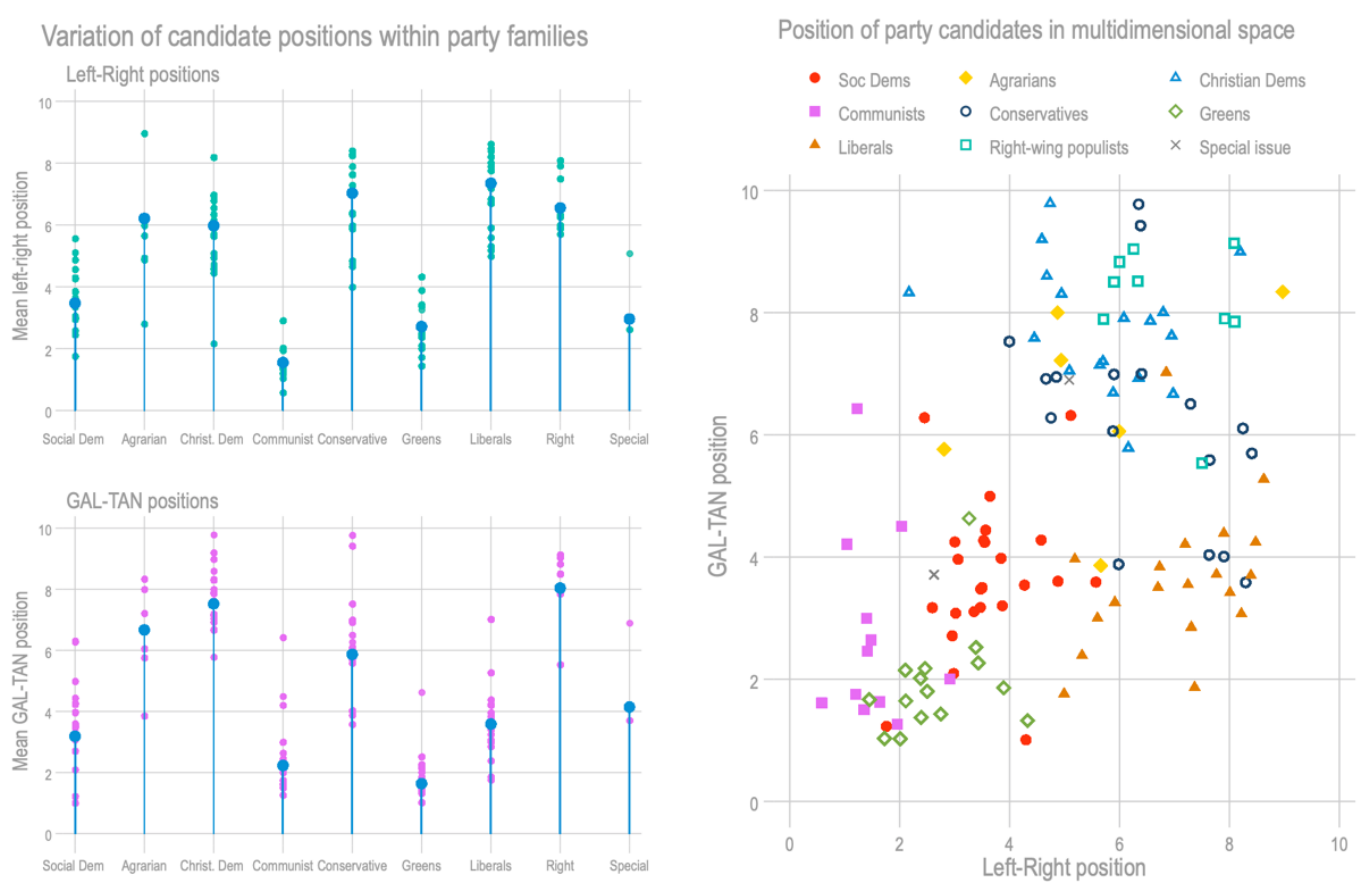

The left-hand panels of Figure 2 demonstrate that whilst European party families' mean ideological positions are distinct, regardless of which axis is considered, there is still a large amount of within-family variation. The right-hand panel of Figure 2 maps the ideological position of Europe's party families across the twodimensional space. Taking Communist and Conservative parties as two illustrative examples, the figure shows that in the case of both party families there are individual parties that fall across various values of the postmaterialist GAL-TAN ideological space. Party ideology, independent of party identity, is therefore likely to play a role in determining candidate preferences on SSM. In line with the findings of Siegel and Wang (2018), we theorize that the correlation between ideological positions and preferences towards SSM will be greater for the GAL-TAN dimension than it will be for the more general left-right axis, which focuses more on market-based economic issues. 
H2a (Ideology Thesis): Candidates belonging to parties holding positions further to the left on the classic political spectrum are more likely to oppose an SSM ban.

H2b: Candidates belonging to parties holding positions further to the left on the post-materialist political spectrum are more likely to oppose an SSM ban.

The alternative to the party-based and ideological model for the legislative successes, and failures, for LGBT rights is that legislative voting on these issues is so-called "morality politics": a unique subset of policy areas where partisanship is far less likely to play a constraining and incentivizing role over legislators' preferences (Engeli, Green-Pedersen, and Larsen 2012). Policy concerns that have typically been tagged within the umbrella of morality concerns include, amongst others, embryo and stem-cell research (Arzheimer 2015, 2020; Banchoff 2011), reproductive rights, euthanasia (Adam, Knill, and Budde 2020; Engeli, Green-Pedersen, and Larsen 2013), and SSM rights (Adam, Knill, and Budde 2020). Morality issues are distinct from "bread and butter" politics in that public and legislators' views on these issues are more likely to be informed by a core set of fundamental values unique to the individual that makes them less amenable to partisan cues and whips (Engeli, Green-Pedersen, and Larsen 2012; Mooney 2001).

As Engeli et al. (2012) argue, individual attitudes towards homosexuality and gay rights are formed long before parties communicate their positions on the issues. Positions on morality issues, sometimes stemming from either a person's religion or degree of religious observance, are formed early on in an individual's formative years, involve high levels of socialization, and are difficult to change (Goren and Chapp 2017). Religious institutions and beliefs have long been a primary mechanism by which individuals develop their attitudes towards societal issues, including towards homosexuality and other concrete policy debates related to the LGBT community such as SSM, adoption rights, or gender recognition. Generally, more secular countries are more tolerant of homosexuality or become more tolerant as traditional sources of identity formation lose their relevancy (Asal, Sommer, and Harwood 2013; Inglehart 1977; Oppenheimer, Oliveira, and Blumenthal 2014). This dynamic generally holds irrespective of religious creed (Olson, Cadge, and Harrison 2006). Most Western monotheistic religions condemned and prohibited homosexual relations under their religious doctrine although evidence from Europe shows majority-mainline Protestant countries are more likely to adopt SSP/SSM laws sooner than Catholic ones (Adam, Knill, and Budde 2020; Kollman 2013), and there is evidence of higher levels of homonegative attitudes among Orthodox Christians, Muslims and evangelical Protestants than among Catholics (Brajdić Vuković and Štulhofer 2012). More specifically, when individuals believe that homosexuality is a moral choice, as taught among most traditional or orthodox interpretations of the Hebrew Bible in Western, monotheistic religions, rather than an uncontrollable, innate characteristic, individuals are likely to register opposition to it and pro-LGBT legislation (Haider-Markel and Jolsyn 2008). Of note is that the negative correlation between religiosity and homonegative sentiment also translates into biases at the ballot box. Magni 
and Reynolds (2020) provide cross-national experimental evidence that non-heterosexual candidates suffer a significantly higher electoral penalty among religious voters than they do among non-religious voters.

Anecdotal evidence shows the importance of an individual legislator's beliefs for MPs' voting behaviour on LGBT rights. For example, SSM only advanced in Germany when Chancellor Angela Merkel permitted a free vote in the Bundestag in 2017. Whether or not Chancellor Merkel allowed the free vote because she had changed her attitudes toward same-sex couples to eliminate a possible salient election issue that rallied her governing coalition's political opponents, the free vote exposed rifts within her own coalition over SSM when 25 percent of CDU parliamentarians voted in favour of SSM and Chancellor Merkel herself voting against it, suggesting private beliefs of the morality of SSM still affected many Bundestag's members, even though the main motivation to hold the vote was to diffuse a salient election issue used by the opposition. ${ }^{6}$ Similar events were observed when the UK's House of Commons introduced SSM in England and Wales in 2013. Despite the legislation being tabled by the Conservative-led Conservative-Liberal Democrat coalition, a majority of the Conservative party's MPs voted against the bill with SSM only passing because of opposition party support (Turnbull-Dugarte 2020b).

H3 (Religiosity Thesis): A candidate's religiosity affects their opposition to an SSM ban, even when conditioning on partisanship.

Would-be MPs' positions on SSM are also likely determined by core demographic factors such as gender, age, family status and education. On average, men are found to be less tolerant of homosexuality than women. In the United States, for example, Twenge and Blake (2020) show that, conditioned on generational replacement across cohorts, women are more likely to be supportive of SSM than their male counterparts (Twenge and Blake 2020). Notably, in the case of the successful referendum on a constitutional prohibition to same-sex marriage in Croatia, Glaurdić and Vuković (2016) observe a significant positive correlation between those municipalities with an older voting population and increased support for the ban, although the electoral margin for the left or right coalition of parties in a municipality also played a strong role in the level of support for an SSM ban in 2013 (Glaurdić and Vuković 2016). Older voters typically have more conservative social values and, therefore, tend to be less tolerant of sexual minorities and more opposed to policies that expand the rights of the LGBT community (Dotti Sani and Quaranta 2020). People who are married with children tend to be less tolerant than those who are single or divorced (Dejowski 1992), and people who live in communities where marriage rates are higher are less tolerant (McVeigh and Diaz 2009). Those with higher levels of education have consistently shown to be accepting of sexual minorities, especially those who completed a university degree

\footnotetext{
${ }^{6}$ Deutscher Bundestag, Namentliche Abstimmung: Eheschließung für Personen gleichen Geschlechts, June 30, 2017,
} https://www.bundestag.de/parlament/plenum/abstimmung/abstimmung/?id=486 (accessed November 14, 2020) 
(Dotti Sani and Quaranta 2020; Stubager 2009). Thus, we test the role of partisanship and religiosity against a battery of socio-demographic factors.

Finally, when considering parliamentary candidates from across Europe, we consider the continuing divide between post-communist and capitalist countries in Europe over social values. While post-communist countries, on average, are less wealthy and economically developed than Western, capitalist ones, low levels of development alone do not predict higher rates of homonegativity. Instead, lower levels of tolerance are attributed to the lingering effects of Soviet ideology that suggests homosexuality is associated with decadent Western values (Janos 2001), the more substantial role religion has in politics in some post-communist countries (Ayoub 2014; Grzymala-Busse 2015), or how conservative religious values and national identity have been fused together in some post-communist countries to oppose the import of culturally progressive norms (Ayoub 2014; Mos 2020; O’Dwyer 2012), although these factors' effects also vary across CEE countries and political parties from left to right. Thus, we expect that candidates from post-communist countries are more likely to support a SSM ban than their peers from the same party families in Western Europe.

\section{Data Description and Analysis}

To analyse the factors that shape candidates' attitudes towards SSM, the Comparative Candidates Survey (CCS) provides a range of information concerning the policy positions, attitudes, and socio-demographic background of parliamentary candidates running for office. The CCS is the only dataset we know of that uses approximately the same uniform questionnaire for candidates across multiple countries and times. Both challengers and incumbents are included across several countries and election cycles in two waves over five years between 2005 and 2013 and again between 2013 and 2018. This yields a sample of over 27,000 parliamentary candidates. Some countries are surveyed more than once, with some surveyed as often as three times across the entire period.

Respondents (candidates) were matched to the ideological party families to which they belong, relying on the party family typology applied by ParlGov (Döring and Manow 2019). The distribution of candidates along the ideological spectrum in the sample roughly matches the size of the parties in European countries. For instance, a majority of respondents came from the five largest European party families-Christian Democrats, Conservatives, Liberals, Greens and Social Democrats. Socio-demographic information about the candidates was also gathered, including income, age, level of education, gender, marital status, faith, and degree of religious observance. Summary and descriptive statistics are located in Appendix Tables A1-3.

When estimating support for LGBT rights among the general public, public opinion surveys ask individuals about their general attitudes or level of support for gay rights or about specific support for SSM or SSP (e.g., World Values Survey, European Values Survey), tolerance of homosexuality, or experience with discrimination (e.g. Eurobarometer). In contrast, the CCS measures support for LGBT rights gauged by candidates' responses concerning the specific item of legislation: whether a ban on SSM should be adopted. The advantage of this 
question over those in public surveys is that it requires respondents to take a specific policy position on the issue of same-sex marriage rather than just express their diffuse attitudes towards homosexuality or LGBT rights. The question elicits what specific action a candidate might take on LGBT rights rather than just acting as a political thermometer and, thus, is a better indicator that would estimate what a politician will do when considering parliamentary legislation. More importantly, and as demonstrated by Mos (2020), SSM prohibitions via constitutional amendments have been on the rise in a number of European states. Asking candidates about SSM prohibitions is, therefore, an effective measure as it solicits candidates' attitudes towards policy reforms that have actively been taking place. There are no other survey instruments that measure attitudes towards sexual minorities or any concrete LGBT rights issues included in the CCS.

Responses measure the extent to which candidates agree with a ban from strongly agree (1) to strongly disagree (5), which was asked in all survey waves, although the wording shifted according to whether SSM already existed or not. ${ }^{7}$ We transform the response variable from ordinal to dichotomous: indicating if a respondent either disagreed or strongly disagreed with an SSM ban (1) or otherwise (0). Doing so not only simplifies the analysis but better conceptualizes whether a candidate supports equal treatment for same-sex couples. The response "neither agree nor disagree" is coded as supportive of an SSM ban as indifference by individuals is unlikely to produce active opposition to discriminatory legislation.

Our first independent variable measures partisanship. To detect party effects, we assigned a categorical variable to each European party family to which a candidate's party belongs according to the classification by Döring and Manow (2019). Social democratic parties are adopted as the reference category for two reasons. First, they make up one of the largest party families in Europe. Second, social democratic parties have tended to be the primary proponents of advancement in LGBT rights legislation (Hildebrandt 2016; Turnbull-Dugarte 2020a) and, therefore, where we expect to see the highest level of opposition to the prohibition of SSM.

Next, we indicate a candidate ideology along two separate ideological dimensions - the general left-light (state-market) dimension and the GAL-TAN 8 axis. We include both the ideological variables and the party family indicators as within party families there is still some important variation across the two dimensions of conflict we include (recall Figure 2).

To measure a candidate's religiosity, we rely on a candidate's level of reported frequency of religious attendance at four levels. We assume that higher levels of religious attendance indicate a person will have more

\footnotetext{
${ }^{7}$ In both survey waves, candidates were asked to what extent they agree that "same-sex marriages should be prohibited by law." However, since same-sex marriage was legal in Belgium starting in 2003, Belgian candidates were asked the degree they agreed "the marriages of gay/lesbians should be furthermore recognized," and the responses reversed to match responses to the former question. Similarly, in 2006 in Czechia, candidates were asked the degree to which they agreed that "it is good that a registered partnership of homosexuals exists," and the responses reversed.

${ }^{8}$ Ideological preferences are measures at the party level. This is important as expert assigned GAL-TAN values are likely to consider the party's position on SSM when it comes to evaluating a party's overall GAL-TAN position. Given that expect individual candidate preferences on SSM to be influenced by individual-level determinants independent of party positions, including the party's GAL-TAN position is an important test of this expectation.
} 
conservative social values than those who do not, and they are more likely to be strongly held (Inglehart 1977; Olson, Cadge, and Harrison 2006). Specifically, there is not likely to be a linear relationship between religious attendance and a person's attitudes to SSM or other moral issues. Instead, people who attend religious services at different levels have qualitatively different positions on moral issues. For instance, those who attend religious services only for major holidays are likely to have liberal social values as much as those who never attend religious services, while those who attend frequently or at least once per month are likely to strongly hold conservative social values and oppose SSM. Using frequency of attendance at religious services as a proxy for a person's religiosity is not without its shortcomings (Rossi and Scappini 2014). Instead of observance, the religious values of different faiths inculcate among their followers may matter more than how often they attend religious worship. For example, religiously observant followers of Universalist/Unitarian Churches support many forms of LGBT equality, while many Catholics may oppose SSM solely because the Church's teachings, even if they attend mass infrequently. Yet, because our sample overwhelming contains individuals identifying as belonging to either mainline Protestant or the Roman Catholic Church and few from non-mainstream Protestant denominations, we set this issue aside for now.

We test the role of our primary explanatory variables—Party ID, political ideology and religion-whilst also controlling for a baseline model of socio-demographic factors including gender, marital status, age and level of education. In addition to these individual-level variables, we also include a dichotomous indicator to identify variable candidates who come from a capitalist (1) or post-communist regime (0). To detect temporal variation, we control for the year in which the candidate was surveyed. Given observations represent party candidates within different European countries, we estimate a multi-level logistic regression model. Relying on a multi-level model with countries as the hierarchical unit allows us to control for unobserved and important between-state variation and the clustered distribution of individual respondents.

\section{Results}

Table 1 reports the output of four different hierarchical logistic regression models estimating support for an SSM ban amongst would-be MPs. All models include the post-communist fixed-effects and temporal trends. Model 1 reports the logit coefficient on opposition to an SSM ban when considering our baseline layer of covariates and religious observance. Model 2 replicates the baseline model with the addition of Party ID, and Model 3 repeats the baseline estimation to include the two ideological measures. Finally, Model 4 considers the effect of all of our independent variables simultaneously. ${ }^{9}$

\section{Table 1: Logistic regression models on opposition to an SSM ban}

\begin{tabular}{llccc}
\hline $\mathrm{X}$ & Model 1 & Model 2 & Model 3 & Model 4 \\
\hline
\end{tabular}

\footnotetext{
${ }_{9}$ Results are reported in this stepwise fashion given the potential for multicollinearity between party ideology and party family. Testing for this via variance inflation factor (VIF) tests does not report any VIF values above 5.
} 


\begin{tabular}{|c|c|c|c|c|}
\hline Gender (ref: woman) & $\begin{array}{c}-0.49 * * * \\
(0.04)\end{array}$ & $\begin{array}{c}-0.41 * * * \\
(0.04)\end{array}$ & $\begin{array}{c}-0.36 * * * \\
(0.04)\end{array}$ & $\begin{array}{c}-0.38^{* * *} \\
(0.04)\end{array}$ \\
\hline \multicolumn{5}{|l|}{ Age (ref: 25-44) } \\
\hline $45-64$ & $\begin{array}{c}0.50^{* * *} \\
(0.10)\end{array}$ & $\begin{array}{c}0.41 * * * \\
(0.10)\end{array}$ & $\begin{array}{c}0.43^{* * *} \\
(0.10)\end{array}$ & $\begin{array}{c}0.43^{* * *} \\
(0.10)\end{array}$ \\
\hline $65-84$ & $\begin{array}{l}0.69 * * * \\
(0.10)\end{array}$ & $\begin{array}{l}0.66^{* * *} \\
(0.10)\end{array}$ & $\begin{array}{l}0.68^{* * *} \\
(0.11)\end{array}$ & $\begin{array}{l}0.69^{* * *} \\
(0.11)\end{array}$ \\
\hline $85+$ & $\begin{array}{l}0.22 * * \\
(0.10)\end{array}$ & $\begin{array}{c}0.18 \\
(0.11)\end{array}$ & $\begin{array}{c}0.15 \\
(0.11)\end{array}$ & $\begin{array}{c}0.15 \\
(0.11)\end{array}$ \\
\hline \multicolumn{5}{|l|}{ Education (ref: Primary) } \\
\hline Secondary & $\begin{array}{c}0.39 * * * \\
(0.14)\end{array}$ & $\begin{array}{c}0.41 * * * \\
(0.14)\end{array}$ & $\begin{array}{c}0.41 * * * \\
(0.15)\end{array}$ & $\begin{array}{c}0.43^{* * *} \\
(0.15)\end{array}$ \\
\hline Post-secondary & $\begin{array}{c}0.82^{* * *} \\
(0.13)\end{array}$ & $\begin{array}{c}0.74 * * * \\
(0.14)\end{array}$ & $\begin{array}{c}0.70^{* * *} \\
(0.14)\end{array}$ & $\begin{array}{c}0.75^{* * *} \\
(0.14)\end{array}$ \\
\hline Married & $\begin{array}{c}-0.18^{* * *} \\
(0.04)\end{array}$ & $\begin{array}{c}-0.17 * * * \\
(0.05)\end{array}$ & $\begin{array}{c}-0.17 * * * \\
(0.05)\end{array}$ & $\begin{array}{c}-0.18^{* * *} \\
(0.05)\end{array}$ \\
\hline \multicolumn{5}{|c|}{ Religious attendance (ref: never) } \\
\hline Rarely/once a year & $\begin{array}{c}-0.57 * * * \\
(0.06)\end{array}$ & $\begin{array}{c}-0.36 * * * \\
(0.06)\end{array}$ & $\begin{array}{c}-0.37 * * * \\
(0.07)\end{array}$ & $\begin{array}{c}-0.37 * * * \\
(0.07)\end{array}$ \\
\hline Few times a year & $\begin{array}{c}-1.12^{* * *} \\
(0.06)\end{array}$ & $\begin{array}{c}-0.68^{* * *} \\
(0.06)\end{array}$ & $\begin{array}{c}-0.71 * * * \\
(0.06)\end{array}$ & $\begin{array}{c}-0.71 * * * \\
(0.06)\end{array}$ \\
\hline Numerous times a month & $\begin{array}{c}-2.42^{* * *} \\
(0.07)\end{array}$ & $\begin{array}{c}-1.69 * * * \\
(0.07)\end{array}$ & $\begin{array}{c}-1.66 * * * \\
(0.07)\end{array}$ & $\begin{array}{c}-1.59 * * * \\
(0.08)\end{array}$ \\
\hline \multicolumn{5}{|l|}{$\begin{array}{l}\text { Party Family (ref: Social } \\
\text { Democrat) }\end{array}$} \\
\hline Agrarian & & $\begin{array}{c}-1.79 * * * \\
(0.09)\end{array}$ & & $\begin{array}{c}0.15 \\
(0.14)\end{array}$ \\
\hline Christian Democrat & & $\begin{array}{c}-1.99 * * * \\
(0.07)\end{array}$ & & $\begin{array}{l}-0.11 \\
(0.12)\end{array}$ \\
\hline Communist & & $\begin{array}{c}0.13 \\
(0.10)\end{array}$ & & $\begin{array}{c}-0.52 * * * \\
(0.11)\end{array}$ \\
\hline Conservative & & $\begin{array}{c}-1.46^{* * *} \\
(0.08)\end{array}$ & & $\begin{array}{c}0.16 \\
(0.13)\end{array}$ \\
\hline Greens & & $\begin{array}{l}-0.13^{*} \\
(0.08)\end{array}$ & & $\begin{array}{c}-0.87 * * * \\
(0.09)\end{array}$ \\
\hline Liberal & & $\begin{array}{c}-0.80 * * * \\
(0.07)\end{array}$ & & $\begin{array}{c}0.01 \\
(0.11)\end{array}$ \\
\hline Right-wing Populist & & $\begin{array}{c}-1.78^{* * *} \\
(0.09)\end{array}$ & & $\begin{array}{l}0.35^{* *} \\
(0.14)\end{array}$ \\
\hline Special issue & & $\begin{array}{l}-0.07 \\
(0.24)\end{array}$ & & $\begin{array}{c}0.79 \\
(0.70)\end{array}$ \\
\hline Ideology: left-right & & & $\begin{array}{c}-0.08 * * * \\
(0.01)\end{array}$ & $\begin{array}{c}-0.14 * * * \\
(0.02)\end{array}$ \\
\hline Ideology: Gal-TAN & & & $\begin{array}{c}-0.30 * * * \\
(0.01)\end{array}$ & $\begin{array}{c}-0.36^{* * *} \\
(0.02)\end{array}$ \\
\hline Post-communist country & $\begin{array}{c}-1.90 * * * \\
(0.51)\end{array}$ & $\begin{array}{c}-1.94 * * * \\
(0.58)\end{array}$ & $\begin{array}{c}-1.86 * * * \\
(0.54)\end{array}$ & $\begin{array}{c}-1.87 * * * \\
(0.56)\end{array}$ \\
\hline Year & $\begin{array}{c}0.14^{* * * *} \\
(0.01)\end{array}$ & $\begin{array}{c}0.15^{* * *} \\
(0.01)\end{array}$ & $\begin{array}{c}0.16^{* * *} \\
(0.01)\end{array}$ & $\begin{array}{c}0.16^{* * *} \\
(0.01)\end{array}$ \\
\hline Constant (Country) & $\begin{array}{c}0.79 * * * \\
(0.26)\end{array}$ & $\begin{array}{c}1.04 * * * \\
(0.35)\end{array}$ & $\begin{array}{c}0.88^{* * *} \\
(0.29)\end{array}$ & $\begin{array}{c}0.96 * * * \\
(0.32)\end{array}$ \\
\hline Constant & $-280.36 * * *$ & $-307.01 * * *$ & $-324.09 * * *$ & $-323.46^{* * *}$ \\
\hline
\end{tabular}




\section{Robust standard errors in parentheses} *** $\mathrm{p}<0.01, * * \mathrm{p}<0.05, * \mathrm{p}<0.1$

We begin by discussing the correlation between the baseline covariates and our main outcome. In line with expectations, we find that male candidates are significantly less likely to oppose an SSM ban. The effect of age, however, is less intuitive; older candidates are, on average, significantly more likely to oppose prohibiting SSM in comparison to their younger colleagues. ${ }^{10}$ Higher educational levels are associated with increased opposition to an SSM ban and married candidates are significantly less opposed to bans on SSM. The coefficients on increased religious observance are negative and significant. Intuitively, and in line with $\mathrm{H} 3$, these findings signal that those who attend more religious services are less likely to oppose a ban on SSM. The point-estimate of these socio-demographic controls is constant across all models reported in Table 1.

Model 2 adds party family identification. The reported coefficients of the different party IDs are largely in line with expectations (H1): Agrarians, Christian Democrats, Conservatives, Liberals and Populist Radical Right-wing parties are all less likely to oppose an SSM ban vis-à-vis the Social Democratic baseline. Controlling for partisanship, religiosity still has a significant and independent effect on a candidate's attitudes towards SSM.

Model 3 demonstrates the effect of these ideological variables without including Party ID, and Model 4 replicates Model 3 to include Party ID alongside ideology. As expected, a candidate's position on the GALTAN dimension is more strongly correlated with attitudes towards SSM than positions on the classic left-right political spectrum. For ease of interpretation and a direct comparison of effect magnitude, Figure 3 visualizes the average marginal effect (AME) of a one-unit change in each variable on the probability of opposing an SSM ban. The AME of a one-unit change in GAL-TAN position is -4.3 percentage-points whilst a one-unit change in left-right position is equal to -1.1 percentage points.

Notably, including indicators of Party ID alongside these ideological measures (right-hand panel Figure 3| Model 4), the substance and significance of the ideological variables remain largely constant at -5 and -2 percentage points respectively. Much of the variation explained by Party ID, however, decreases when considering a candidate's political ideology. There is no statistically significant difference between the probability of opposing the prohibition of SSM between Social Democratic candidates and Christian Democratic candidates or candidates from Liberal parties. Where we do observe a significant gap, however, is in the case of the Green party or Communist party. The former is 12 percentage points less likely to oppose

\footnotetext{
10 In our primary analysis, we model age as a categorical indicator. Replications including age (years) and age-squared are reported in Figure A1 and replicate the findings here.
} 
the prohibition of SSM, whereas the effect is close to 7.2 percentage points in the case of the Communists, which is highly counter-intuitive given these parties are traditional perceived as strong supporters of LGBT rights.

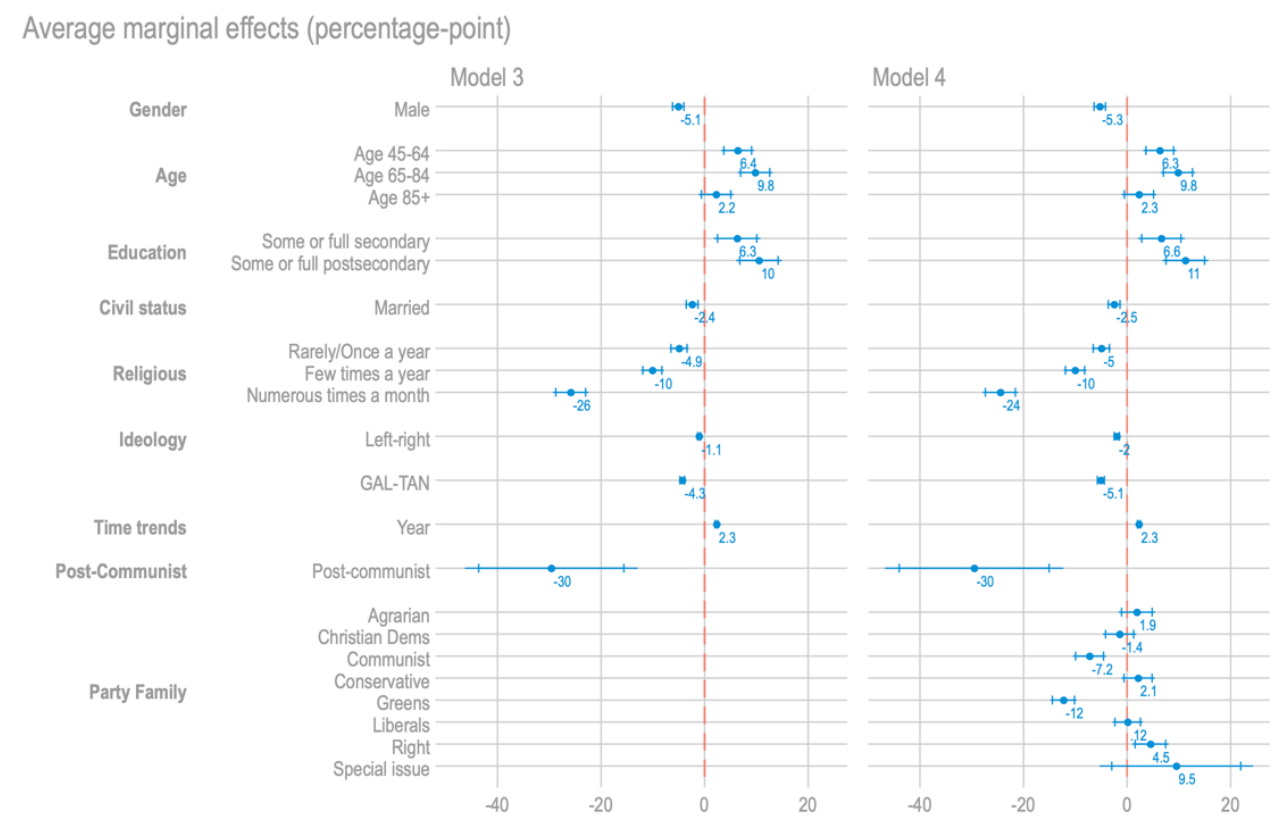

The longitudinal nature of the CCS data allows us to test for the potential variability in the effect of ideology over time. An exploratory analysis of the role both ideological indicators exhibit on SSM attitudes across different years demonstrates that over time the correlation between ideological positions and SSM preferences has actually increased (see Appendix Figure A5).

Why are both Communists and Greens, traditionally found on the far-left side of both the materialist and postmaterialist political spectrums both less likely to oppose SSM bans compared with Social Democrats as the baseline? The answer lies in the powerful effect religion has on candidates' views. First, amongst the individuallevel variables, religiosity (indicated by religious attendance) is one of the most powerful determinants of our outcome of interest. Candidates who report increased religious observance are significantly more likely to support prohibiting equal treatment for same-sex couples than those who never attend religious service. Compared to those who do not attend religious services at all, those who attend once per year are 5 percentage points more likely to support an SSM ban, and this gap increases to a substantive 24 percentage-point disparity when comparing those who attend church on (at least) a monthly basis and those who never attend. At the same time, religiosity does not vary significantly across members of different party families.

Second, Green and Communist party candidates are not as secular as perhaps assumed in the literature. In our sample, only about 30 percent of Green/ecological party candidates do not attend religious services at 
all in our sample. These figures are not significantly different from candidates who belong to other party families further to the right: 26 percent of Conservative parties, 31 percent of Christian Democratic parties, and even 27 percent of the Socialist party family attend religious services a few times per year.

Third, a person's level of religious observance or religiosity also explains within-party variation opposition to an SSM ban. Figure 4 shows predicted outcomes of different levels of religious attendance conditioned by party families. For example, whilst secular Social Democratic candidates have a predicted probability of opposing an SSM ban in surplus of 80 percent, candidates from the same party family who attend church at least once monthly are more than 20 percentage-points $(p<0.01)$ less likely to oppose the same ban. A similar pattern is observed among members of Liberal parties, Christian Democrats as well as members of Green and Communist parties.

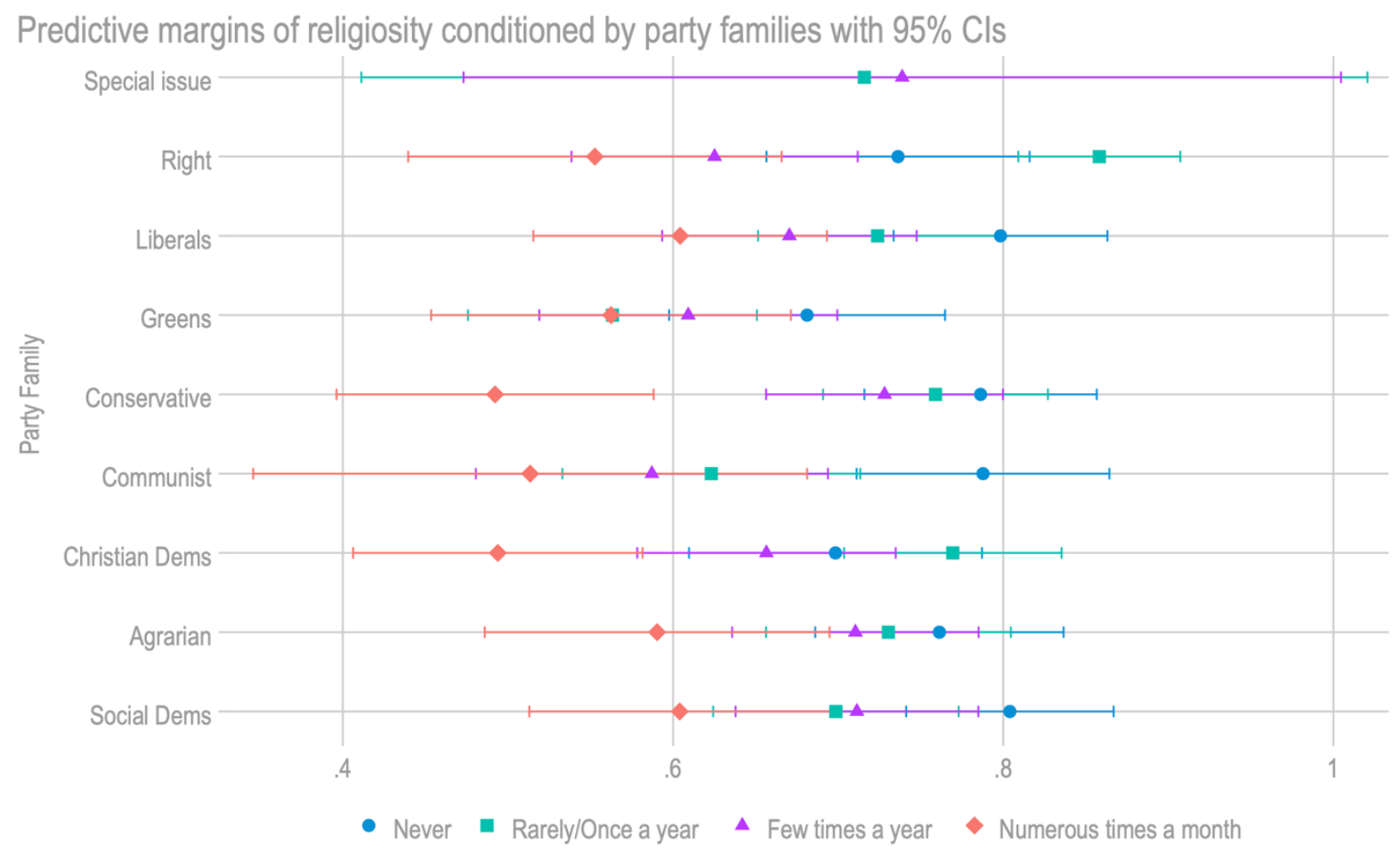

Replication of Model 4 with addition of multiplicative interaction between Religiosity and Party family ID

These counter-intuitive results show that though cultural values are ingrained in people's lives, and religion still shapes politicians' attitudes towards LGBT rights, despite the dual pressures of being required to follow the party's positions on LGBT rights, whether left or right, and changing public opinion. It is also consistent with Arzheimer (2020) who shows that, once one considers religiosity, partisanship plays a far more diminished role in determining MPs' positions on morality issues like embryonic testing than how religious a person is. Furthermore, every party and party family are composed of candidates who attend religious services to different degrees. These differences exist across different party systems. There is a secular-religious cleavage in most 
advanced democracies. It is unsurprising to find that levels of religious observance within two-party systems, as they try to capture ideologically similar members across different levels of religious observance. We would expect in multi-party systems that religious candidates are concentrated in one or more parties, particularly on the right. However, our results show this is not a safe assumption. Levels of religiosity vary significantly within parties and, therefore, the positions candidates will have on equal treatment for LGBT individuals are also likely to differ. One implication is that if more "free votes" are taken on LGBT issues, the passage of LGBT equality legislation depends on more secular candidates gaining parliamentary representation.

\section{Conclusion}

The factors pushing for the advancement of LGBT equality are happening at multiple levels. At the micro level, public opinion polls have shown increasing levels of tolerance for same-sex sexual relations, same-sex marriage, and other examples of pro-LGBT human rights legislation. At the most macro level, international norms and institutions, often in collaboration with transnational activists, are putting pressure on national governments from "above." In most countries in Europe, these pressures are filtered through national parliaments, with some governments acting as leaders and others laggards compared to the state of national public opinion. One possible reason some parliaments were laggards is that their members tended to be more socially conservative on morality issues than the general public (Arzheimer 2020).

This is the first study of its kind utilizing an under-explored dataset to explore the attitudes of European parliamentary candidates over a key public policy debate with regards to LGBT rights. We find that a candidate's degree of religious observance plays a strong role in whether they supported a ban on same-sex marriage, irrespective of political ideology or party identification. Even among parties typically the home of progressive cultural positions, such as the Greens, religious observance affects a candidate's support for an SSM ban. However, the effect of religious observance has diminished over time. Instead, as LGBT rights have become less of a matter of private belief and more a point of public, political contestation, where the parties stand on the post-materialist spectrum and LGBT rights as an election issue will matter more.

Knowing the preferences candidates have over SSM does not necessarily tell us if and how pro-LGBT legislation adopted and when. Election dynamics, the views of party leaders, or international legal pressures are powerful drivers of policy change. And these data only reveal the views of candidates for office, not their voting behaviour once in office, when they may act against their own personal views on SSM. Instead, they may follow the party line or what their constituents desire, which may or may not conflict with their own personal views. But knowing candidates' preferences is a first step to investigating the nature of the link between representatives and their constituents over a controversial issue of human rights and policy change.

If politicians' personal values are more conservative (or progressive) than large public majorities, they will be facing increasing tension between casting votes on LGBT rights according to their personal moral beliefs and their constituents' views in some cases. This is not always the case. As evidenced in the United States 
(Bishin, Freebourn, and Teten 2020), although larger percentages of the general public are increasingly supportive of LGBT rights and equality, political elites are becoming more polarized over them, suggesting there could be less, rather than more, congruence between the will of democratic majorities and the positions of their elected representatives with regard of LGBT human rights and equal treatment, depending on a representative's political constituency. Thus, policy change would depend either on how representation is structured or what political elites believe and how those beliefs change over time, such as through increased minority representation. However, previous research finds that politicians' values are highly stable over time (Searing, Jacoby, and Tyner 2017). Alternatively, LGBT rights legislation may happen through official replacement, whereby a new generation of more secular, cosmopolitan MPs approve the passage LGBT legislation. These puzzles are not just relevant to the politics of LGBT rights. Explanations for why and how members of parliaments respond to domestic and international pressures for policy change apply to other morality policies, such as euthanasia, gender equality, and the regulation of controlled substances. Additional research, thus, is needed to assess if and when democratic representatives bend to the will of their constituents' changing moral beliefs, or whether social change depends on changing the hearts and minds of representatives themselves.

\section{Supplementary Data Appendix}

A data appendix containing data replication files is located at https://doi.org/10.7910/DVN/NNG2KV.

\section{Funding}

This work was supported by an independent grant by the Office of the Dean of Liberal and Creative Arts at San Francisco State University. Brian Olinger was also a recipient of a Marcus Undergraduate Student Travel Grant in 2019.

\section{Conflict of interest statement}

The authors declare no conflicts of interest

\section{Acknowledgements}

Earlier iterations of this work benefitted from the critical and helpful feedback from participants of the 2020 Southern Political Science Association Conference, the 2020 American Political Science Association Conference, and the 2021 Council for European Studies Conference. Attendees of the Queer Politics at Princeton seminar also provided useful comments which greatly improved the paper. Finally, we thank the four anonymous reviewers for their critical engagement and close reading of our manuscript. 


\section{Biographical note}

Dr. Scott Siegel is an Associate Professor in International Relations at San Francisco State University. His research interests focus on contemporary issues in European politics and the party politics of the treatment of social minorities.

Dr. Stuart J. Turnbull-Dugarte is an Assistant Professor in Political Science at the University of Southampton. His research is based at the intersection between political sociology and comparative politics.

Brian Olinger is an independent scholar and 2011 graduate of San Francisco State University. He has held internships at the Carter Center in Atlanta, Georgia and US State Department and currently works in the Middle East.

\section{Bibliography}

Abou-Chadi, Tarik, and Ryan Finnigan. 2019. "Rights for Same-Sex Couples and Public Attitudes Toward Gays and Lesbians in Europe." Comparative Political Studies 52(6): 868-95.

Adam, Christian, Christoph Knill, and Emma T. Budde. 2020. "How Morality Politics Determine Morality Policy Output-Partisan Effects on Morality Policy Change.” Journal of European Public Policy 27(7): 101533.

Arzheimer, Kai. 2015. "Strange Bedfellows: The Bundestag's Free Vote on Pre-Implantation Genetic Diagnosis (PGD) Reveals How Germany's Restrictive Bioethics Legislation Is Shaped by a Christian Democratic/New Left Issue-Coalition." Research \& Politics 2(3): 1-7.

Arzheimer, Kai. 2020. "Secular Citizens, Pious MPs: Why German Attitudes about Genetic Testing Are Much More Permissive than German Laws." Political Research Exchange 2(1): 1-25.

Asal, Victor, Udi Sommer, and Paul G. Harwood. 2013. "Original Sin: A Cross-National Study of the Legality of Homosexual Acts.” Comparative Political Studies 46(3): 320-51.

Ayoub, Phillip M. 2014. "With Arms Wide Shut: Threat Perception, Norm Reception, and Mobilized Resistance to LGBT Rights." Journal of Human Rights 13(3): 337-62.

Ayoub, Phillip M. 2016. When States Come out: Europe's Sexual Minorities and the Politics of Visibility. Cambridge: Cambridge University Press.

Ayoub, Phillip M., and Jeremiah Garretson. 2017. "Getting the Message Out: Media Context and Global Changes in Attitudes Toward Homosexuality." Comparative Political Studies 50(8): 1055-85.

Ayoub, Phillip M., and Kelly Kollman. 2020. "(Same)-Sex in the City: Urbanisation and LGBTI Rights Expansion." European Journal of Political Research Online First.

Banchoff, Thomas. 2011. Embryo Politics: Ethics and Policy in Atlantic Democracies Embryo Politics: Ethics and Policy in Atlantic Democracies. New York: Cornell University Press.

Bishin, Benjamin G, Justin Freebourn, and Paul Teten. 2020. "The Power of Equality? Polarization and Collective Mis-Representation on Gay Rights in Congress, 1989-2019.” Political Research Quarterly OnlineFirst.

Bishin, Benjamin G, Thomas J Hayes, Matthew B. Incantalupo, and Charles Anthony Smith. 2020. "Elite 
Mobilization: A Theory Explaining Opposition to Gay Rights.” Law and Society Review 54(1): 233-64.

Brajdić Vuković, Marija, and Aleksander Štulhofer. 2012. "'The Whole Universe Is Heterosexual!' Correlates of Homonegativity in Seven South-East European Countries." In The Aftermath of War, eds. Kristen Ringdal and Albert Simkus. Ashgate, 217-34.

Cowley, Philip. 1998. "Unbridled Passions? Free Votes, Issues of Conscience and the Accountability of British Members of Parliament." Journal of Legislative Studies 4(2): 70-88.

Dejowski, E F. 1992. "Public Endorsement of Restrictions on Three Aspects of Free Expression by Homosexuals: Socio-Demographic and Trends Analysis 1973-1988." Journal of Homosexuality 23(4): 1-18.

Döring, Holger, and Philip Manow. 2019. "Parliaments and Governments Database (ParlGov): Information on Parties, Elections and Cabinets in Modern Democracies."

Dotti Sani, Giulia M., and Mario Quaranta. 2020. "Let Them Be, Not Adopt: General Attitudes Towards Gays and Lesbians and Specific Attitudes Towards Adoption by Same-Sex Couples in 22 European Countries." Social Indicators Research 150(1): 351-73.

Engeli, Isabelle, Christoffer Green-Pedersen, and Lars Thorup Larsen. 2012. "Theoretical Perspectives on Morality Issues." In Morality Politics in Western Europe. Parties, Agendas and Policy Choices, eds. Isabelle Engeli, Christoffer Green-Pedersen, and Lars Thorup Larsen. Basingstoke: Palgrave MacMillan, 5-26.

Engeli, Isabelle, Christoffer Green-Pedersen, and Lars Thorup Larsen. 2013. "The Puzzle of Permissiveness: Understanding Policy Processes Concerning Morality Issues.” Journal of European Public Policy 20(3): 33552.

Flores, Andrew R., and Scott Barclay. 2016. "Backlash, Consensus, Legitimacy, or Polarization: The Effect of Same-Sex Marriage Policy on Mass Attitudes.” Political Research Quarterly 69(1): 43-56.

Garretson, Jeremiah J. 2018. The Path to Gay Rights: How Activism and Coming Out Changed Public Opinion. New York: NYU Press.

Glaurdić, Josip, and Vuk Vuković. 2016. "Proxy Politics, Economic Protest, or Traditionalist Backlash: Croatia's Referendum on the Constitutional Definition of Marriage." Europe - Asia Studies 68(5): 803-25.

Goren, Paul, and Christopher Chapp. 2017. "Moral Power: How Public Opinion on Culture War Issues Shapes Partisan Predispositions and Religious Orientations." American Political Science Review 111(1): 110 28.

Grzymala-Busse, Anna. 2015. Nations under God: How Churches Use Moral Authority to Influence Policy. Princeton: Princeton University Press.

Haider-Markel, Donald P, and Mark R Jolsyn. 2008. "Beliefs About the Origins of Homosexuality and Support for Gay Rights: An Empirical Test of Attribution Theory.” Public Opinion Quarterly 72(2): 291310.

Helfer, Laurence R., and Erik Voeten. 2014. "International Courts as Agents of Legal Change: Evidence from LGBT Rights in Europe.” International Organization 68(1): 77-110.

Hildebrandt, Achim. 2016. "Who's in Favour? Same-Sex Union Laws in Parliament." The Journal of Legislative Studies 22(3): 404-23.

Inglehart, Ronald F. 1977. The Silent Revolution: Changing Values and Political Styles among Western Publics. New Jersey: Princeton University Press.

Janos, Andrew C. 2001. "From Eastern Empire to Western Hegemony: East Central Europe Under Two International Regimes." East European Politics and Society 15(2): 221-29.

Kollman, Kelly. 2013. The Same-Sex Unions Revolution in Western Democracies: International Norms and Domestic Policy Change. Manchester: Manchester University Press.

Kollman, Kelly. 2017. "Pioneering Marriage for Same-Sex Couples in the Netherlands." Journal of European Public Policy 24(1): 100-118.

Magni, Gabriele, and Andrew Reynolds. 2020. "Voter Preferences and the Political Underrepresentation of Minority Groups: Lesbian, Gay, and Transgender Candidates in Advanced Democracies." Journal of Politics Online Fir.

McVeigh, Rory, and Maria Elena Diaz. 2009. "Voting to Ban Same-Sex Marriage: Interests, Values, and Communities.” American Sociological Review 74(6): 891-915.

Mooney, Christopher Z. 2001. "The Public Clash of Private Values." In The Public Clash of Private Values. The Politics of Morality Policy, ed. Christopher Z. Mooney. Washington: CQ Press, 3-18. 
Mos, Martijn. 2020. “The Anticipatory Politics of Homophobia: Explaining Constitutional Bans on Same-Sex Marriage in Post-Communist Europe." East European Politics 36(3): 395-416.

O'Dwyer, Conor. 2012. "Does the EU Help or Hinder Gay-Rights Movements in Post-Communist Europe? The Case of Poland." East European Politics 28(4): 332-52.

Olson, Laura R, Wendy Cadge, and James Harrison. 2006. "Religion and Public Opinion about Same-Sex Marriage." Social Science Quarterly 87(2): 340-60.

Oppenheimer, David, Alvaro Oliveira, and Aaron Blumenthal. 2014. "Religiosity and Same-Sex Marriage in the United States and Europe.” Berkley Journal of International Law 32(1): 195-238.

Paternotte, David, and Kelly Kollman. 2013. "Regulating Intimate Relationships in the European Polity: Same-Sex Unions and Policy Convergence.” Social Politics 20(4): 510-33.

Plumb, Alison. 2015. "How Do MPs in Westminster-Style Parliaments Vote When Unconstrained by Party Discipline? A Comparison of Free Vote Patterns on Marriage Equality Legislation." Parliamentary Affairs 68: 533-54.

Rossi, Maurizio, and Ettore Scappini. 2014. "Church Attendance, Problems of Measurement, and Interpreting Indicators: A Study of Religious Practice in the United States, 1975-2010." Journal for the Scientific Study of Religion 53(2): 249-67.

Searing, Donald D, William G Jacoby, and Andrew H Tyner. 2017. “The Endurance of Politicians' Values Over Four Decades: A Panel Study." American Political Science Review 113(1): 226-41.

Siegel, Scott N, and Yiqian Alice Wang. 2018. "Broken Rainbows: The Partisan Politics of Marriage Equality in Europe." European Politics and Society 19(4): 377-95.

Stubager, Rune. 2009. "Education-Based Group Identity and Consciousness in the Authoritarian-Libertarian Value Conflict." European Journal of Political Research 48(2): 204-33.

Thomeer, Mieke Beth, Allen J. LeBlanc, David M. Frost, and Kayla Bowen. 2018. “Anticipatory Minority Stressors among Same-Sex Couples: A Relationship Timeline Approach.” Social Psychology Quarterly 81(2): $126-48$.

Trumm, Siim, Caitlin Milazzo, and Joshua Townsley. 2020. "The 2016 Referendum: Explaining Support for Brexit among Would-Be MPs.” Political Studies OnlineFirst.

Turnbull-Dugarte, Stuart J. 2020a. "The European Lavender Vote: Sexuality, Ideology and Vote Choice in Western Europe.” European Journal of Political Research 57(3): 517-37.

Turnbull-Dugarte, Stuart J. 2020b. "Who Wins the UK Lavender Vote? (Mostly) Labour.” Politics, Groups, and Identities Online First.

Twenge, Jean M., and Andrew B. Blake. 2020. "Increased Support for Same-Sex Marriage in the US:

Disentangling Age, Period, and Cohort Effects." Journal of Homosexuality Online First. 